GRZEGORZ TWARDOWSKI*

\title{
Twórcza droga do architektury i jej wpływ na jakość mieszkalnictwa
}

\section{The creative path to architecture and its impact on the quality of housing}

Streszczenie

elem pracy jest odnajdywanie sensu architektury, pokazywanie roli i znaczenia kompozycji i formy w twórczej drodze ku zuace twórcza droge która podzzaja artyści oderwani od historyzmu Rozważania ida w kierunku odczytywania architektury nade wszystko intencii twórcy jako przekazów myśli. Poszukiwanie podobieństw w dziełach wybitnych artystów, tworzacych wielkie dzieła sztuki.

The aim of the work is to find the sense of architecture, to show the role and importance of composition and form in the creative process towards architecture in a residential environment. Significant examples of architectural works from the late are directed to were selected, showing the creative path followed by artists detached from historicism. The considerations similarities in the works of outstanding artists that create great works of art.

Słowa kluczowe: architektura, pięnno, forma
Keywords: architecture, beauty, form

"Słucha się reggae, ogląda westerny, obiad je się wą, używa się paryskich perfum w Tokio, w Hongkong urządza się mieszkania w stylu retro, wiedza staje sie rzedmiotem teleturnie

"Przez wiele lat sztuka, architektura były związane mocno z kanonem estetycznym określonej epoki. Te zaś były oparte przede wszystkim na wynikach abstrakcyjnych spekulacji nad strukturą liczb i figur geometrycznych"2. Historycznie, reguł piękna poszukiwano $w$ architekturze przedstawionej za pomocą liczb, boskiej proporcji, rytw. Wiek XX odzacil wszelle dotychczasowe zasady, wstępując w nowa ere architektury idei i form, które przyniosly wielki dziela szćć. „Architektura dziś istniepzoza nutáni sztuki. Wsród innych sztuk wyroźnia ja w kregu doktryn funkcjonalistycznych."3 Dziś tworze-

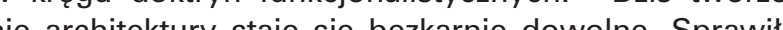
Cace'owska wizja, że muzyka może być wszystko co uznamy za muzyke Jego niestychanie awangardowe 4'33" - dzieło, które może wykonać każdy. Wystarczy przecież wpatrywać sie uważnie w zegarek który odmiepa wyznaczony przez artyste czas kompozycii utwor muzycznego . Cage przeczy owej ciagłości kulturowe $w$ sposób znaczący - $i$ to jest może jego najmocniejsza bronią." ${ }^{4}$ Czymże zatem jest architektura? Ta niejednoznaczna i trudna do opisania definicja została osadzon

People listen to reggae, watch westerns, eat lunch at perfumes from Paris are used in Tokyo, Hong Kong partments are arranged in the style of retro, know "Fer becomes the subject of TV quiz shows ve bee trongly associated with the aesthetic canon of a giva and the by numbers, divine proportions, rhythms. The 20th entury rejected all previous rules, entering a new era of architecture of ideas and forms that were brought by great works of art. "Architecture today exists outside of the movements of art. Among other arts, it is distinguished by its usefulness. Contemporary architecture still exists the circle of functionalist doctrines. Today, creation of architecture is becoming free of any bounds. It was Cage's vision that music could be anything that we want to consider music. 列 could create. It is merely enough to look carefully a reating the composition of the musical work. "Cage contradicts this cultural continuity in a significant way - and this is perhaps his strongest weapon."4 What is architecture, then? This ambiguous and difficult to de-
"W racjonalnym systemie teoretycznym".$^{5}$ Wypada dzis zgodzic się z Philipem Johnsonem, Kory widzi forme wyplywającą z poprzedzającej ją formy, nie z funkc "form follows previous form, not function", co oponuje do słów Louisa Sullivana - forma podąża za funkcja "form follows function.. Tworcza droga do architektury prowadzi przez przejrzyste układy kompozycyjne, aż do jakiejś logicznej i przejrzystej struktury, ktora byc moż zostanie nazwana dziełem sztuki. Rozważania te prowa dza do istoty kompozycji, ktora tworzy całość dzieła. Maria Golaszewska, pisząc o kulurze estetyki, uznaje ją „jako jedną z mozzliwości $w$ dażeniu do pełnego, optymalnego rozwoju czlowieka, do pogłębienia jego

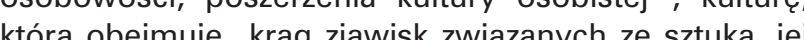
ktora obejmuje "krąg zjawisk zwazzanych ze sztuka, jej

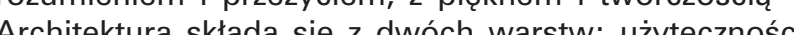
Arcormy w przeszeni zunkcii prymarnych i seku darnychu Użyteczność hulajnogi śwityni czy szklaki wydaje sie oczywista i nie da sie jej kwestionować Lecz najpierw, widz spostrzega ksztatt tych rzeczy, to co estetyczne. Sama funkcjonalność schodzi na drugi plan, badź nawet pozostaje ukryta w świadomości cztowieka. Sens owego przesłania widzi Dariusz Kozłowski w swoim artystycznym credo: „Co będzie jednak, gdy barwy wyblakna, idee zostana zapomniane, jezyk architektury stanie sie niezrozumiały, a konwencje uznane za dziwaczne i zbyteczne? Jeżeli pozostaną „bramy«, "wieże", "świątynie", "budowle", albo tylko bryły widniejące w świetle, i w mroku, i w ciemności - pozostanie architektura. Co potwierdzi tezę, że - architektura jest sztuką budowania rzeczy fikcyjnych tak, by wyglądały jak prawdziwe." ${ }^{\prime 8}$ Wielu twórców architektury widzi ją jako cos więcej niz tylko budowla, ale jako częsc budowania swoistej wiedzy. Maria Misiągiewicz pisze, ze "talent ar-

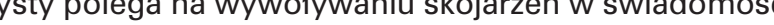
lub poza świadomością autora. [...] architektura moż nie zadawalać myślenia o budowli jedynie przez to, co $w$ niej materialne.

Monumentalny Pałac Abraxas, Riccardo Bofilla i grupy Taller pod Paryżem zbudowany w 1983 roku (II. 1.), forma dająca poczucie harmonil, tak ważna we wszystkich definicjach piękna, przestzen odwolująca się do architekury neoklasycznej, przedstawia Teatr, tuk i Pałac. Pałac nazwany na czesc czarodzieja, stynącego z za-

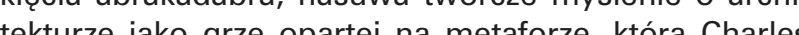
Jenck jazyo gra nasuma tworcze mys tzy budyni, nasycone reprezentacyiny charakterem, zozmieszczone w przestrzeni barokowei, tworzac wspaniała przestrzeń, w której monumentalność sta nowi to dla naiszlachetniejszego obszaru zabudowy mieszkaniowej. Rytm kolumnad, kryjacych windy, dzie wieciokondygnacyina szklana kolumnada od strony dziedzińca, podtrzymujaca doryckie betonowe kapitee, została zwieńczona smukłymi cyprysami na dachu. [...]amfiteatr został wizualnie równo podzielony na trzy piętra; bliźnie kolumny toskański maja trzy kondygnacje wysokości, nadając przyjemny rytm oknom." 10 Dziewieciokondygnacyjne szklane kolumny teatru podtrzymuja potrojny kapitel, tworząc zakrzywiony blok mieszkalny scribe definition has been set "in a rational theoretica who claims the form results from the preceding form, not from the function form follows the previous form, not function", which contradicts the words of Lou's Sullivan - the form follows the function "form follows (o a logical and transparent structure that may be called a work of art These considerations lead to the essence of the composition that creates the whole of the work of art. Maria Gołaszewska, writing about the culture of aesthetics, recognizes it as "one of the possibilities in the pursuit of a full, optimal development of man, to deepen his personality, to broaden his propriety"6, culture which includes "the circle of phenomena connected with art, its understanding and experience, with beauty and creativity.. Architecture consists of two layers: usability and form in space; "primary and secondary glass seems obvious and unquestionable But first the viewer perceives the shape of these things, the aesthetic. Functionality itself goes to the background or even remains hidden in human consciousness. The sense of this message is noticed by Dariusz Kozłowski in his artistic credo: "But what will happen when the colours fade, ideas get forgotten, the language of architecture becomes incomprehensible and conventions become considered as bizarre and redundant? If there remain "gates", "towers", "temples", "buildings", or only figures seen in light, in darkness and in blackness architecture will remain. Which confirms the thesis in such a way that they look as if they were real ${ }^{8} \mathrm{Many}$ creators of architecture see it as something more than just a building, but as a part of building knowledge. ria Misiagiewicz writes that "the talent of an artist consists in evoking associations in the consciousness or Outside of the author's consciousness. [...] architecture of its material properties. ${ }^{9}$

The monumental Abraxas Palace, built by Riccardo Bofill and the Taller group near Paris in 1983, a form that gives a sense of harmony, so important in all definitions of beauty, a space referring to neoclassica Palace. The prescents the Thealre, the Arc and the for his spell "abracadabra", inspir a sorcerer famous about architecture as a game based on metaphor, which Charles Jencks calls "the miraculous para-

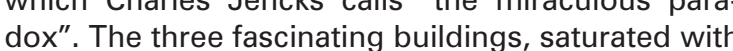
a representative character, are located in a baroque space, creating a wonderful space in which monumentality is the background for the most noble residentialy is the backgrom the colonnades, covering 列 concte cap. three equalfors; the twin Tuscan columns heve thro evels of height, giving a pleasant rhythm to the win(10ws."10 The nine-storey glass columns of the theatre support the triple capitol, forming a curved block of flats marking the square: Ricardo Bofil was convinced 
jest bez wątpienia klasą mistrzowską na temat asymilacji obiektu architektonicznego w otaczającą tkankę miejska. Wskazany przykład wydaje się potwierdzac słowa Tomasza Kozlowskiego, który pisze o unikaniu potrzeby badania tzw. motywacji urbanistycznych: „Pewna sytuacja przestrzenna ma tu szczególną rolę, zwalnia architekta od badania motywacji urbanistycznych: to "sytuacja narożnikowau, teren wyznaczony ulicami zbiegającymi się pod kątem (najlepiej ostrym) wskazującymi linie zabudowy." 15 Czysta geometria oparta na ideach ma wielk wartość, jako środek twórczego myślenia w drodze do pociągającej, wyrafinowanej sztuki.

W zupełnie innej przestrzeni pluralizmu oceny gustów populistycznych i elitarnych znajduje się Casa Sperimentale, Dom eksperymentalny (II. 3.), zaprojektowany przez i syna Uga De Plaisant; zbudowany w Fregene w 1968 roku. To najardziej niezwykte dzieto eksperymentalne i awangardowe záwno pod wzgledem formy, ja i wykorzystania materiatów, które odnoszą sie do bruta listycznej architektury, kojarzonej z szorstkim, surowym betonem. Ekspresyina forma domu budzi skojarzenie z Frankensteinem, brutalizmem Paula Rudolpha i mo dernizmem Le Corbusiera. Wrażenie lewitacii budowl wśród długich i tajemniczych pni sosnowego lasu, wywołuje skojarzenie z gniazdem czy domem na drzewie. Perugini wybrał beton zbrojony o niewygładzonych płaszczyznach, pozostawiając ślady niedokładności wykonania odlewu, który uzupełniany jest czerwonymi stalowymi elementami w kształcie krzyża. Dom Peruginiego tworzą trzy eksperymentalne przestrzenie, z czego głównym jest Casa Albero, tzw. Nieskończony Dom stanowiący modulowy system betonowych ram. Wnętrza stanowią multiplikację przestrzeni, podłóg, poprzez autorski system przeszkleh, kore w nietypowy sposob przenika masę betonu, dzięki czemu otwera wnętrze ku nieskończonej przestrzeni natury. Okna pomalowane na czerwono jak wszystkie żelazne elementy dom podkreślają użycie wybranego materiału, tworząc nie skończoną kolorową grę. Czerwona spiralna forma klatki schodowej, jako zwodzony most, stanowi akcent na tle surowej materii betonu. Z ostrej, dynamicznej, linearnej formy wyłaniaja się zaokrąglone kapsuły mieszczące łazienki. Kontapunkt glównej częśsi willi stanowi enigmatyczna kula o srednicy pięciu metrów. W rozgrywajacym się teatrze archicektury, może wlasnie o takiej rzeczy tworza juz prostych form. Posługujac sie wyliczeniami inżynierowie stosuia formy geometryczne, zadowalajace nasze oczy geometria a umyst - matematyka; ich dzieta prowadza do wielkiej sztuki."16 To efektowne dzieto sztuki stanowiace potaczenie konstruktywistyczego ra cionalizmu i pozaziemskich fascynacii. Budynek miat po kazać ślady brutalności w procesie budowy, pokazujac konstruktywny jezyk zbrojonego betonu. Jak podkreśla Dariusz Kozłowski: Beton ma dusze. To metaforyczn stwierdzenie przywołuje najpierw skojarzenie antropomorficzne - oglądając rzecz architektoniczną z betonu obcujemy z jej zewnetrznością, oglądamy jej "skórę by ocenić formę. Można zobaczyć moc materiału, sity przebiegające wewnątrz konstrukcji [...] Niekiedy moż- seems to confirm the words of Tomasz Kozlowski, who whes about avoiding "he need to study the so-called a special role to play here, it relieves the architect of the eed to study urban motivations: it is a "corner situaton", an area marked by streets converging at an angle (preferably sharp) indicating the lines of the developmay to attractive, sophisticated art

In a completely different space of pluralism of populist and elite tastes assessments, there is Casa Sperimentale, an experimental house, designed by Giuseppe Perugini, his wife Raynaldo Perugini and son Uga De Plaisant; built in Fregene in 1968. It is he most remarkable experimental and avant-garde work in terms of both form and use of materials tha refer to the brutalist architecture, usually associated the hough, raw conseciations with Frankm Paul Rudolph's brutalism and Le Corbusier's mein ernism. The impression of levitation of the building among the long and mysterious trunks of a pine forest evokes associations with a nest or a tree house. Perugini chose reinforced concrete with uneven surfaces, leaving traces of inaccuracy in the casting, which is complemented by red, cross-shaped stee elements. Perugini's House consists of three experimental spaces, the main one being Casa Albero, the so-called House of the Infinite, which is a modular system of concrete frames. The interiors are a muem of glazing which in an unusual way penetrates the mass of concrete, thus opening the interior to the infinite space of nature. The windows painted red like all iron elements of the house, emphasize the use of the chosen material, creating an infinite colourfu game. The red spiral form of the staircase, as a drawbridge, is an accent with the background of raw concrete matter. From the sharp, dynamic, linear form rounded capsules emerge, which house the bathrooms. The counterpoint to the main part of the villa is an enigmatic ball with a diameter of five metres. Corbusier was thinking aboure, maybe that's what Le day's architects no longer create simple forms. ing calculations, engineers use geometric forms that satisfy our eyes with geometry and our minds with mathematics; their works lead to great art."16 It is an mpressive work of art combining constructivist ratio nalism and extraterrestrial fascination. The building was supposed to show traces of brutality in the construction process, showing a constructive language of reinforced concrete. As Dariusz Kozłowski emphasizes: "Concrete has a soul. This metaphorical statement first evokes an anthropomorphic association - looking in antact with its exteriority, we look at its ckin in order to assess its form. One can see the power of the material, the forces running inside the construction [...] Sometimes one can see the soul of concrete -when the shape of the thing reveals the only possible combination - beauty, purpose, durability of the product of human imagination." ${ }^{17}$.For Perugini, born na ujrzeć duszę betonu - gdy kształt rzeczy ujawni to jedyne z moziliwych polączen - piękna, celo losci wytworu ludzkiej wyobraznin. Dla Peruginiego, urgentynie, architektura byla wyzwoleniem, ekstatycznym marzeniem o mechanicznej przyszłości, w której nie widział sprzeczności. Być może była to romantyczna dusza współczesnosci: przestrzegał ra cjonalnych zasad, zabierając je na skrajne i niezbadan terytoria, gdzie stały się poetycką materią. Przekształc wizję maszyny $z$ symbolu doskonałości w dynamiczná fascynacje wywołaniem chaosu z kalwinowską lekkoscią, eliminując ideologiczny ciężar rosyjskich konstruktywistow oraz wloskich futurystów. Obnazanie niezwykłe scenerî Casa Sperimentale jest nieustannym blądze-

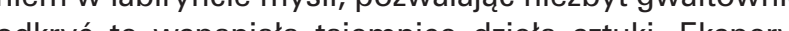
mo czéć brutalistycznej architektury, po smierci architaktów popadta w ruine Tomasz Kozlowski wska zuje, iz ruina niesie ze soba pewna semantyke nostal za przeszłościa - nieznana więc wypetniona możliwościami uzupełniania jej obrazu dowolnymi projekcjami. Ruina nadaje doskonale sie jako uscenografiau do konfabulacji historii poetyckiej, tajemniczej, lub strasznej."10 Niewatpliwie dzieło Peruginiego stało sie najbardziej unikalna budowla-rzeźba w nadmorskiej miejscowośc Fregene, a Jego twórcza droga do architektury naprowadza nas na stwierdzenie, że architektura modernizmu nie była tylko czystym funkcjonalizmem.

Wypada zakończyć rozważania myśla Juliusza Żórawskiego: „Ogromna jest rozmaitość wyobraźni twórcze Jakże trudno byłoby pisać o niej wiedząc, że cokolwiek by sie nie napisalo, bęzlie to zawsze tylko nieudolne staranie się pokazania czegos, co jest niemoźliwe do ukazania. Zresztą tyle już napisano na ten temat, ze można by najwyżej pokusic się o zreasumowanie tego, co wszyscy znaja, wprowadzając tu lub tam drobną korektę. [... Jest chyba zrozumiałe, ze wyobražnia twórcza nie może stwarzac rzeczy calkiem nowych. Takich, ktore jeszcze nigdy i nigdzie nie istniały w jakiśs sposób. Takich, które przekraczałyby ludzką fantazję lub ludzką pojemnośc psychiczna. " Puentując pewną zabawe w grę z oczywstą funkcją architektury mieszkanioweji jej stawanie się dzielem sztuki, wypada przywolac slowa Władysława Tatarkiewicza, ze "Wartosć artysty leży w oryginalnośc inowosci, ale tę czerpie on ze świata, nie z wymysłów, (lecz z odkryc, ze spostrzeżenia rzeczy, których inni nie

PRZYPISY

Lyotard Jean-François, Odpowied'́n na pytanie: co to jest postmoder-

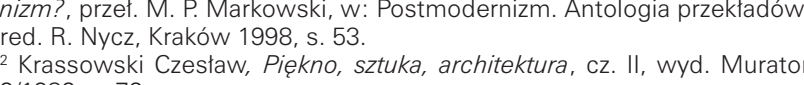

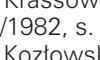
Zeszyty Katedry Architektury Mieszkaniowej nr 3, wyd. IPA, Politechnika 4 Erhardt Ludwik, Szztuka, dźwięku, Wydawnictwa Artystyczne i Filmowe

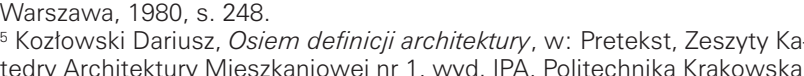

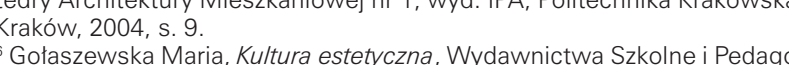
${ }^{6}$ Gołaszewska Maria, Kultura e
giczne, Warszawa, 1979, s. 5. in Argentina, architecture was a liberation, an ecstatic dream of a mechanical future an contradictions. Perhaps it was the romantic soul of contemporary times. he followed rational principles, where they to extreme and unexplored territories Whe vision of the machine from a symbol of perfection into a dynamic fascination with creating phas with Calvinist lightness, eliminating the ideological burde of Russian constructivists and Italian futurists. Exposing the extraordinary scenery of Casa Sperimentale is a constant wandering in the labyrinth of thoughts, allowing this wonderful mystery of a work of art to be discovered not too suddenly. The experimental part of brutalistic architecture, after the architects' deaths, fell bout pastmenting its image with any projections. as a vscenery for confabulating poetic, mysterious or errible history"18 Undoubtedly Perugini's work has become the most unique building and sculpture in the seaside town of Fregene, and his creative path to architecture leads us to the statement that modernism .

th is appropriate to end the deliberations with the the variety of creative whe difteult it would be whatever you wrote, whe thing that is impossible to she ant

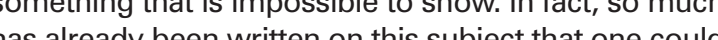
only try to sum up what everyone knows by making a slight correction here or there. [.] It is probably understandable that creative imagination cannot create completely new things. Those that have never and nowhere existed in any way. Such things that would To To put a point to games with the obvious function of The reclill the words of Wladystaw Tatarand far hings that others do not notice". 20

ENDNOTES

Lyotard Jean-François, Odpowiedź na pytanie: co to jest postmo
dernizm? Translated by M. M. Markouski, in: Postmodernizm. An"Krassowski Crestatu, Piekno, szztuka, architektura, part II, pub-

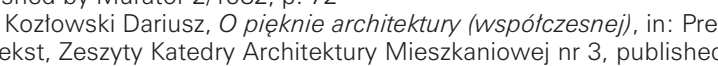
by IPA, Politechniika Krakowska, Cracow, 2003, p. 33.
"Erhardt Ludwik, Sztuka dzwieku, published by Wydawnictwa Artt

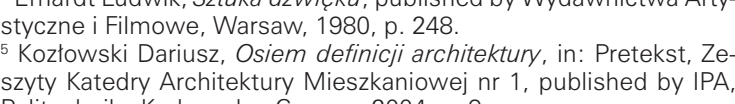
szyty Katedry Architektury Mieszkaniowej $\mathrm{nr}$ 1, published by IPA,
Politechnika Krakowsta. Cracow, 2004, p. 9. Gotaszewska Maria, Kultura estell,
Pedagogiczne, Warsaw, 1979, p. 5 .

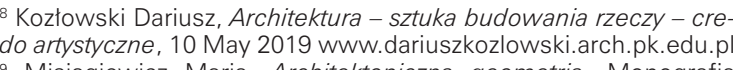
9 Misiagiewicz Maria, Architekttoniczna gaomettria, Monongrafia
245. published by Wydawnictwo Politechniki Krakowskiej, Kraków, 10 encks Charles, Architektura postmodernistrczna, published by
Arkady, Warsaw, 1987, . . 161. 
8 Kozłowski Dariusz, Architektura - sztuka budowania rzeczy - credo artystyczne, (odsłona z dnia 10.05.2019), dostępny w Internecie: www.dariuszkozlowski.arch.pk.edu.pl

${ }^{9}$ Misiągiewicz Maria, Architektoniczna geometria, Monografia 245, wyd. Politechniki Krakowskiej, Kraków, 2005, s. 46.

10 Jencks Charles, Architektura postmodernistyczna, Arkady, Warszawa, 1987, s. 161.

${ }^{11}$ Misiągiewicz Maria, O prezentacji idei architektonicznej, Monografia 245, wyd. Politechniki Krakowskiej, Kraków, 2003, s. 127.

12 Jencks Charles, Architektura postmodernistyczna, Arkady, Warszawa, 1987, s. 160 .

13 Venturi Robert, Brown Denise Scott, Izenour Steven, Uczyć się od Las Vegas. Zapomniana symbolika formy architektonicznej, tłum. Anna Porębska, Karakter, Kraków, 2013

14 Jencks Charles, Architektura postmodernistyczna, Arkady, Warszawa, 1987, s. 151.

${ }^{15}$ Kozłowski Tomasz, Tendencje ekspresjonistyczne w architekturze wspótczesnej, Monografia 445, Wydawnictwo Politechniki Krakowskiej, Kraków, 2013, s. 77.

${ }^{16}$ Le Corbusier, W strone architektury, Fundacja Centrum Architektury, Warszawa. 2012, s.76

${ }_{17}$ Kozłowski Dariusz, O naturze betonu - czyli idee, metafory i abstrakcje, w: Architektura betonowa, D. Kozłowski (red.), Kraków 2001, s. 5.

18 Kozłowski Tomasz, Wątki dekompozycyjne we współczesnej przestrzeni architektonicznej, Praca Doktorska napisana pod kierunkiem Prof. dr hab. inż. arch. Marii Misiągiewicz, na Wydziale Architektury Politechniki Krakowskiej, Kraków 2004, s. 20.

19 Żurawski Juliusz, O budowie formy architektonicznej, Arkady, 1962, s. 181

20 Tatarkiewicz Władysław, Parerga, PWN, Warszawa, 1978, s. 43.

\section{LITERATURA}

[1] Erhardt L., Sztuka dźwięku, Wydawnictwa Artystyczne i Filmowe, Warszawa, 1980

[2] Gołaszewska M., Kultura estetyczna. Wydawnictwa Szkolne i Pedagogiczne, Warszawa, 19795

[3] Jencks C., Architektura postmodernistyczna, Arkady, Warszawa, 1987.

[4] Le Corbusier, W strone architektury, Fundacja Centrum Architektury, Warszawa, 2012

[5] Lyotard J.-F., Odpowiedź na pytanie: co to jest postmodernizm?, przeł. M. P. Markowski, w: Postmodernizm. Antologia przekładów, red. R. Nycz, Kraków 1998

[6] Kozłowski D., Architektura - sztuka budowania rzeczy - credo artystyczne, (odsłona z dnia 10.05.2019), dostępny w Internecie: www.dariuszkozlowski.arch.pk.edu.pl

[7] Kozłowski D., O naturze betonu - czyli idee, metafory i abstrakcje, w: Architektura betonowa, D. Kozłowski (red.). Kraków 2001.

[8] Kozłowski D., O pięknie architektury (współczesnej), w: Pretekst, Zeszyty Katedry Architektury Mieszkaniowej nr 3, wyd. IPA, Politechnika Krakowska, Kraków, 2003.

[9] Kozłowski D., Osiem definicji architektury, w: Pretekst, Zeszyty Katedry Architektury Mieszkaniowej nr 1, wyd. IPA, Politechnika Krakowska, Kraków, 2004.

[10] Kozłowski T Tendencje ekspresjonistyczne w architekturze wspótczesnej, Monografia 445, Wydawnictwo Politechniki Krakowskiej, Kraków, 2013. [11] Kozłowski T., Wątki dekompozycyjne we współczesnej przestrzeni architektonicznej, Praca Doktorska napisana pod kierunkiem Prof. dr hab. inż. arch. Marii Misiagiewicz, na Wydziale Architektury Politechniki Krakowskiej, Kraków 2004.

[12] Misiągiewicz M., Architektoniczna geometria, Monografia 245, wyd. Politechniki Krakowskiej, Kraków, 2005.

[13] Misiągiewicz M., O prezentacji idei architektonicznej, Monografia 245, wyd. Politechniki Krakowskiej, Kraków, 2003.

[14] Krassowski C., Piękno, sztuka, architektura, cz. II, wyd. Murator 2/1982.

[15] Tatarkiewicz W., Parerga, PWN, Warszawa, 1978.

[16] Venturi R., Brown D. S., Izenour S., Uczyć się od Las Vegas. Zapomniana symbolika formy architektonicznej, tłum. Anna Porębska, Karakter, Kraków, 2013.

[17] Żurawski J., O budowie formy architektonicznej, Arkady, 1962.
${ }_{11}$ Misiagiewicz Maria, O prezentacji idei architektonicznej, Monograph 245, published by Wydawnictwo Politechniki Krakowskiej, Cracow, 2003, p. 127

12 Jencks Charles, Architektura postmodernistyczna, publishe by Arkady, Warsaw, 1987, p. 160

${ }^{13}$ Venturi Robert, Brown Denise Scott, Izenour Steven, Uczyć się od Las Vegas. Zapomniana symbolika formy architektonicznej, translated by Anna Porębska, published by Karakter, Cracow, 2013.

14 Jencks Charles, Architektura postmodernistyczna, published by Arkady, Warsaw, 1987, p. 151

15 Kozłowski Tomasz, Tendencje ekspresjonistyczne $w$ architekturze wspótczesnej, Monograph 445, published by Wydawnictwo Politechniki Krakowskiej. Cracow, 2013, p. 77

${ }^{16}$ Le Corbusier, $W$ strone architektury, published by Fundacja Centrum Architektury, Warsaw. 2012, p.76

17 Kozłowski Dariusz, O naturze betonu - czyli idee, metafory $i$ abstrakcje, in: Architektura betonowa, D. Kozłowski (edited), Cracow 2001 , p. 5

18 Kozłowski Tomasz, Wątki dekompozycyjne we współczesnej przestrzeni architektonicznej. Doctoral Thesis written under the guidance of Prof. D.Sc. Ph.D. Arch. Marii Misiagiewicz, Institute of Architectural Design, Faculty of Architecture, Cracow University of Technology, 2004, p. 20

19 Zurawski Juliusz, O budowie formy architektonicznej, published by Arkady, 1962, p. 181

${ }^{20}$ Tatarkiewicz Władysław, Parerga, published by PWN, Warsaw, 1978 , p. 43

\section{BIBLIOGRAPHY}

[1] Erhardt L., Sztuka dźwięku, Wydawnictwa Artystyczne i Filmowe, Warszawa, 1980

[2] Gołaszewska M., Kultura estetyczna, Wydawnictwa Szkolne i Pedagogiczne, Warszawa, 19795.

[3] Jencks C., Architektura postmodernistyczna, Arkady, Warszawa, 1987

[4] Le Corbusier, W strone architektury, Fundacja Centrum Architektury, Warszawa, 2012

[5] Lyotard J.-F., Odpowiedź na pytanie: co to jest postmodernizm? przeł. M. P. Markowski, w: Postmodernizm. Antologia przekładów. red. R. Nycz, Kraków 1998.

[6] Kozłowski D., Architektura - sztuka budowania rzeczy - credo artystyczne, (odsłona z dnia 10.05.2019), dostępny w Internecie: www.dariuszkozlowski.arch.pk.edu.pl

[7] Kozłowski D., O naturze betonu - czyli idee, metafory i abstrakcje, w: Architektura betonowa, D. Kozłowski (red.), Kraków 2001.

[8] Kozłowski D., O pięknie architektury (wspótczesnej), w: Pretekst, Zeszyty Katedry Architektury Mieszkaniowej nr 3, wyd. IPA, Politechnika Krakowska, Kraków, 2003.

[9] Kozłowski D., Osiem definicji architektury, w: Pretekst, Zeszyty Katedry Architektury Mieszkaniowej nr 1, wyd. IPA, Politechnika Krakowska, Kraków, 2004

[10] Kozłowski T., Tendencje ekspresjonistyczne w architekturze współczesnej, Monografia 445, Wydawnictwo Politechniki Krakowskiej, Kraków, 2013

[11] Kozłowski T., Wątki dekompozycyjne we współczesnej przestrzeni architektonicznej. Praca Doktorska napisana pod kierunkiem Prof. dr hab. inż. arch. Marii Misiągiewicz, na Wydziale Architektury Politechniki Krakowskiej, Kraków 2004.

[12] Misiągiewicz M., Architektoniczna geometria, Monografia 245 wyd. Politechniki Krakowskiej, Kraków, 2005.

[13] Misiągiewicz M., O prezentacji idei architektonicznej, Monografia 245, wyd. Politechniki Krakowskiej, Kraków, 2003.

[14] Krassowski C., Piękno, sztuka, architektura, cz. II, wyd. Murator 2/1982.

[15] Tatarkiewicz W., Parerga, PWN, Warszawa, 1978.

[16] Venturi R., Brown D. S., Izenour S., Uczyć się od Las Vegas. Zapomniana symbolika formy architektonicznej, tłum. Anna Porębska, Karakter, Kraków, 2013

[17] Żurawski J., O budowie formy architektonicznej, Arkady, 1962. 